\title{
Structural variation and landward vergence at the toe of the Oregon accretionary prism
}

\author{
Mary E. MacKay \\ Hawai'i Institute of Geophysics and Planetology, School of Ocean and Earth Science and Technology \\ University of Hawai'i Honolulu
}

\begin{abstract}
The Oregon margin near $45^{\circ} \mathrm{N}$ spans a regional transition in structural style from seaward vergence in the south to landward vergence in the north. This variation probably reflects a regional change in both sediment type and rate of deposition that affects the potential for overpressure in the sediments. Structural style within the survey area shows a gradual northward transition from seaward to landward vergence and to lower slopes within the landward vergent area, suggesting a northward decrease in basal shear stress. Superimposed on this gradational variation are abrupt changes in structural style that correlate with NW striking strike-slip faults in the Cascadia Basin. Because sediments thicken toward the east, translation along the strike-slip faults results in juxtaposition of sediments with different physical properties and loading histories. In addition, the faults themselves may act as fluid conduits, resulting in stepwise changes in pore pressure on the décollement and concomitant change in structural style across the faults. Although the OregonWashington margin is dominated by landward vergence, landward vergence has not been adequately explained by theoretical models or replicated in experimental models because of a simple omission in the boundary conditions of the underlying conceptual model. Landward vergence requires not only low basal shear stress but also an arcward dipping décollement (and to a lesser degree, a relatively strong wedge). In order for landward vergence to predominate, these three factors must combine in such a way that the backward verging thrust planes are favored.
\end{abstract}

\section{Introduction}

As sediments are incorporated into an accretionary prism, the structural style of the developing prism records a complex interplay of changing sediment and pore fluid properties with tectonic stress. Because the physical properties are not measurable on a regional scale, the processes controlling deformation and fluid flow at convergent margins have been inferred from variation in structural style. The importance of faults as fluid conduits and the role of overpressure in faulting [e.g., Hubbert and Rubey, 1959] have focused particular attention on pore pressure conditions at the décollement. The décollement is a primary control on the morphology and structural style of the accretionary prism; the strength, or effective stress, at the décollement affects the taper and length of the prism, as well

Copyright 1995 by the American Geophysical Union.

Paper number 95TC02320.

0278-7407/95/95TC-02320\$10.00 as fault geometry and spacing [e.g., Davis et al., 1983; and Platt, 1988]. The stratigraphic position of the décollement also controls the relative thickness of the accreted and underthrust sections. Beneath the prism, rapid loading due to tectonic thickening can produce high pore fluid pressures on the décollement; however, this process often begins seaward of the deformation front, where high sedimentation rates or fluid expulsion from beneath the prism produces high pore fluid pressures and lower effective stress along the potential décollement horizons [Westbrook et al., 1993]. Where several potential décollement horizons are available, high pore fluid pressure may influence the stratigraphic position of the décollement.

The Oregon accretionary prism is an area of active fluid flow and inferred high pore pressures. High-amplitude, reversedpolarity reflectors are common on major faults and in the protothrust zone; these are interpreted as fluid conduits or areas of high pore fluid pressure [Moore et al., 1995; Tobin et al., 1994]. Active fluid flow is observed from vents at the seafloor [Kulm et al., 1986; and Carson et al., 1990] and contributes to slope failure along the front of the marginal ridge [Orange and Breen, 1992]. On a regional scale, the Oregon-Washington margin is characterized by widespread landward vergence, a structural style attributed to low basal shear stress on a weak, overpressured décollement [Seely, 1977].

This paper relates the style of deformation in the frontal fold thrust, where structures are relatively simple, to conditions in the adjacent Cascadia Basin sediments, especially along the incipient décollement. In so doing I hope to answer two questions: (1) what causes landward vergence? and (2) what controls the changes in vergence and structural style at the toe of the Oregon accretionary prism?

\section{Cascadia Basin}

Along the Oregon-Washington margin, upper Miocene (8 Ma) crust of the Juan de Fuca plate is subducted beneath North America (Figure 1) [Kulm et al., 1984] at $42 \mathrm{~mm} / \mathrm{yr}$, directed N69 ${ }^{\circ} \mathrm{E}$ [DeMets et al., 1990]. Pliocene/Pleistocene turbidites fill the Cascadia Basin, eliminating the topographic expression of the trench; the turbidites are divided into two units by a seismic sequence boundary [Kulm et al., 1973, 1984]. The upper unit (Unit I) consists of very fine- to medium-grained sandy turbidites derived from the Astoria Fan north of the study area. The lower unit (Unit II) is composed of east dipping silty turbidites typical of the abyssal plain in the Cascadia Basin [Kulm et al., 1973]. Sediments thicken eastward, reaching a total thickness of 3.5 to $4.0 \mathrm{~km}$ at the toe of the slope. Along strike (approximately $\mathrm{N}-\mathrm{S}$ ), total sediment 


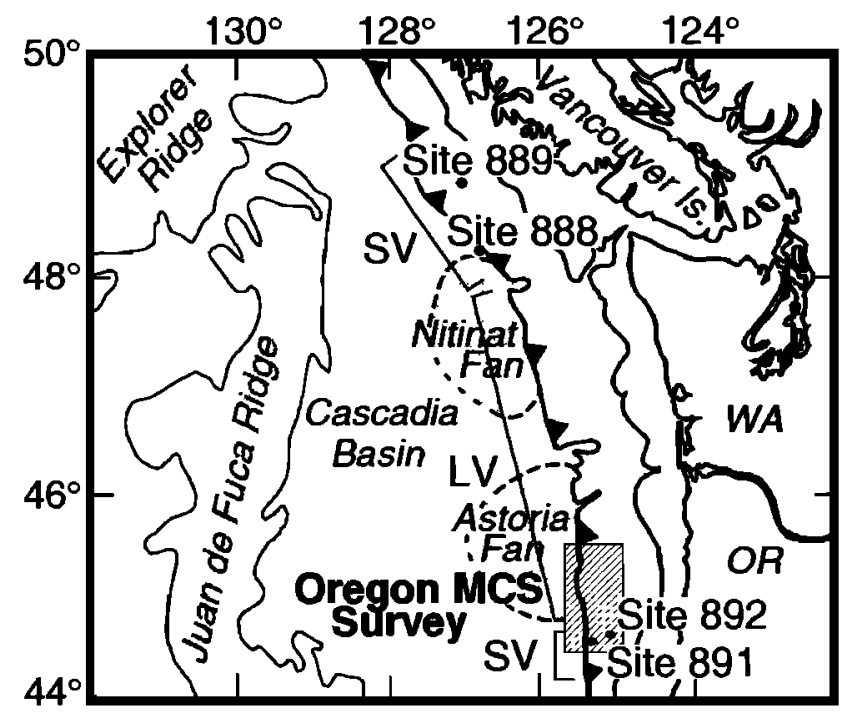

Figure 1. Regional location map. Multichannel seismic reflection (MCS) survey area is in hachured box. Ocean Drilling Program (ODP) sites are shown by solid circles. Vergence changes along the margin; SV is seaward vergence; $\mathrm{LV}$ is landward vergence.

thickness is roughly constant across the survey area; both oceanic crust and seafloor dip gently to the south.

\section{Seismic Data Acquisition and Processing}

We collected over $2000 \mathrm{~km}$ of multichannel seismic reflection (MCS) lines, spaced approximately $1-5 \mathrm{~km}$ apart, along the central and northern Oregon margin (Figure 2) in September 1989, aboard Digicon's Geotide, a commercial seismic vessel. Navigation was by a commercial satellite positioning system. The seismic source was a tuned 4560 inch $^{3}$ air gun array fired at $25-\mathrm{m}$ intervals, and reflections were received by a 144-channel streamer with group spacing of 25 $\mathrm{m}$, yielding 72-fold common midpoint (CMP) data at a CMP interval of $12.5 \mathrm{~m}$. Prestack processing included $t^{2}$ gain, spiking deconvolution, normal moveout correction, stretch mute, and near-trace mute for multiple attenuation. A frequencywavenumber (FK) filter was applied to selected dip lines, including OR-05 and OR-23, for additional multiple attenuation. After stack, the data were time-variant filtered and migrated using a finite-difference algorithm. Lines OR-05 and OR-23 were converted from time to depth using a smoothed version of the stacking velocities.

\section{Initial Deformation in the Accretionary Prism}

The survey area spans a regional transition from seaward vergence in the south to landward vergence in the north (Figure 1). At the toe of the prism, the regional transition in structural style is expressed in four distinct structural domains (Figure 3). The boundaries between the domains are abrupt and correspond to the intersection of NW striking strike-slip faults in the Cascadia Basin with the deformation front and to deformation associated with the strike-slip faults [Appelgate et al., 1992; MacKay et al., 1992; Tobin et al., 1993].
Domain I (Figure 3) is characterized by seaward vergence and a relatively shallow décollement. A protothrust zone, well-developed between shot points (SP) 150 and 400, stretches 5-6 km seaward of the toe of the slope, soling at the level of the incipient décollement (Figure 4a). The east dipping frontal thrust steps upward from the décollement forming a seaward vergent ramp anticline that constitutes the marginal ridge. The marginal ridge anticline is cut by one major, and several minor, west dipping back thrusts. The décollement in this region lies at about $5.6 \mathrm{~s}$ (Figure 4a, SP 350). High-amplitude, reversed-polarity reflectors associated with the frontal thrust, back thrust, and many of the protothrusts in this region

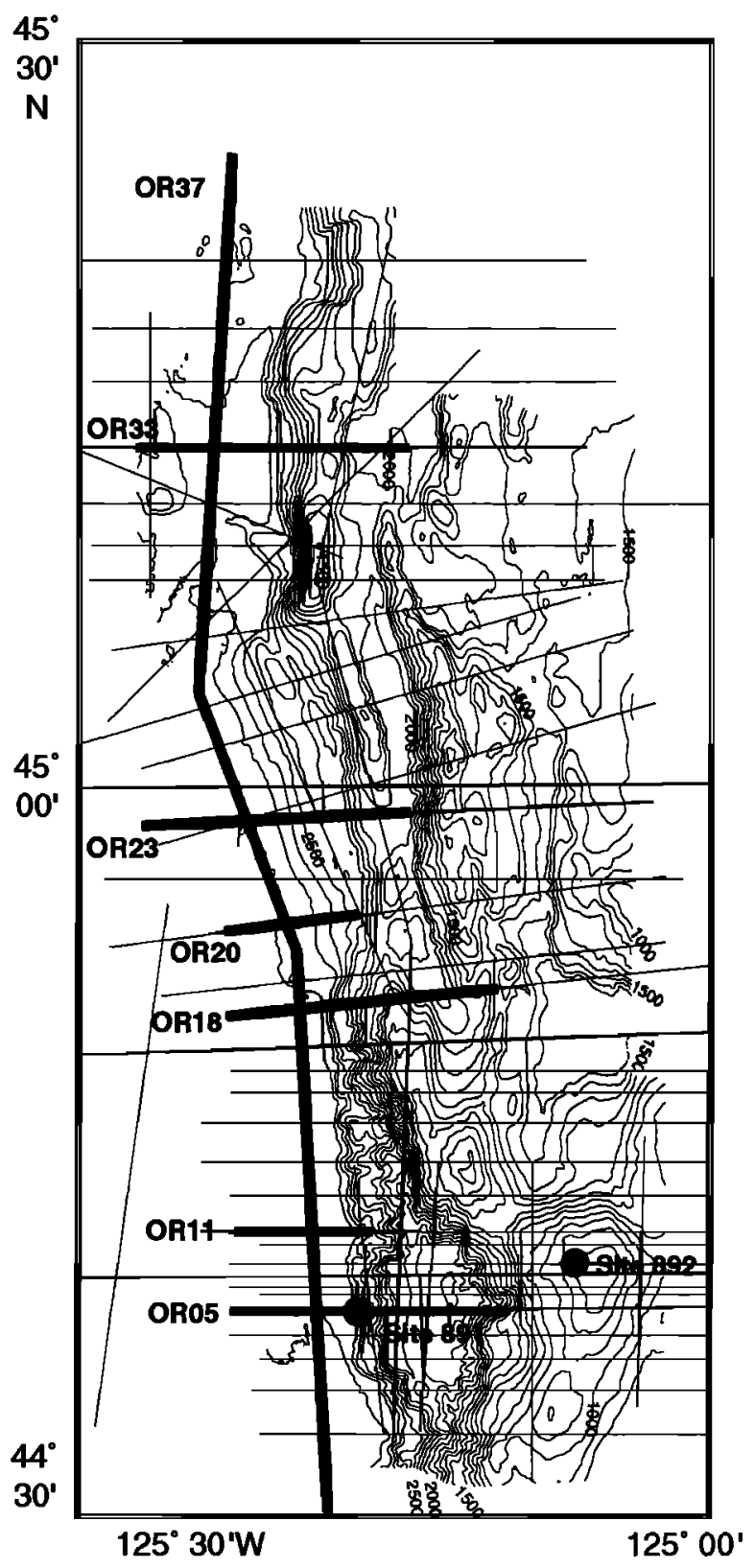

Figure 2. Location map of MCS survey area. MCS lines are shown overlying contoured Sea Beam bathymetry (100-m contour interval). MCS lines discussed in the text are shown in bold. 


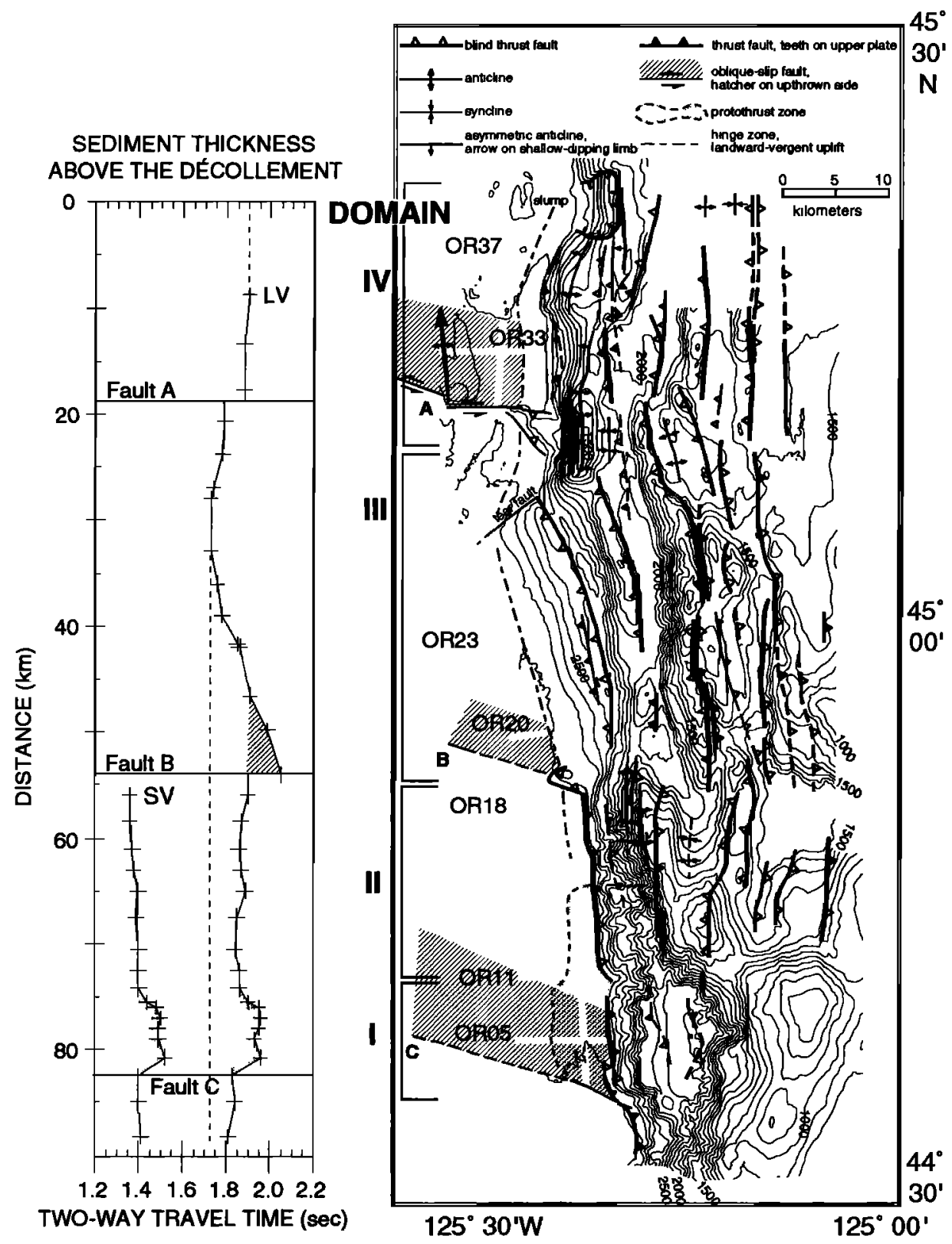

Figure 3. (left) Isopach between horizon $\mathrm{H} 1$ and landward vergent (LV) and seaward vergent (SV) décollements (horizons shown on Plate 1) showing along-strike change of sediment thickness on MCS line OR-37 between these horizons. Hachure shows tectonic thickening due to the uplift associated with strike-slip faults. Stipple shows tectonic thickening due to protothrusts. Increase in thickness above baseline (dashed) south of $32 \mathrm{~km}$ reflects the eastward shift of the MCS line. (right) Structural interpretation of MCS data overlying contoured Sea Beam bathymetry (100-m contour interval). Portions of MSC lines discussed in the text are shown shaded. Hachure shows region of uplift associated with NW striking oblique-slip faults.

have been interpreted as high-porosity, high pore pressure fluid conduits and are associated with fluid vents on many of the lines in this area [Kulm et al., 1986; Carson et al., 1990; Moore et al., 1990, 1995]. The second ridge is underlain by a poorly imaged east dipping thrust and cut by several minor thrusts that are associated with fluid venting to the north [Moore et al., 1991; Westbrook et al., 1993]. The large size and seismic opacity of this second ridge suggest substantial internal fault imbrication [MacKay et al., 1992]; sediments recovered at ODP Site 892 (location shown in Figure 2) were pervasively fractured [Westbrook et al., 1993].

Domain II is also seaward vergent but displays a more coherent style of deformation (deformed sediments retain much of their internal layering), and the anticlinal marginal ridge is more symmetrical than that observed to the south (Figure 4b). A narrow, poorly developed protothrust zone is present across 


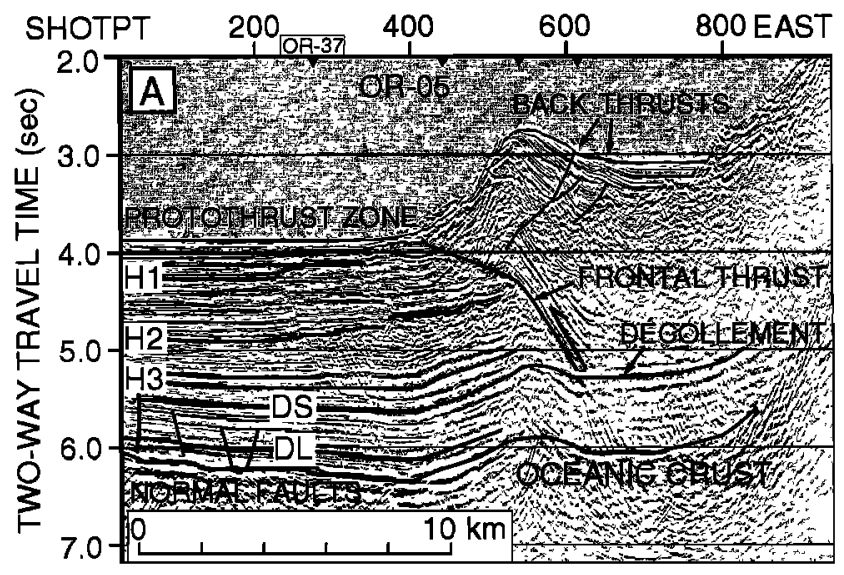

overthrust the seaward limb of the preceding thrust sheet along a west dipping thrust that soles out near the oceanic crust, forming prominent landward vergent ridges (Figure 5a). As opposed to Domain I, protothrusts are rare, and the incoming sediments are not tectonically thickened before being rotated seaward. Almost all of the $2.5 \mathrm{~s}(\sim 4 \mathrm{~km})$ of sediments are offscraped; only about $0.3 \mathrm{~s}(400 \mathrm{~m})$ of sediment is underthrust beneath the slope (Figure 5a). The major thrusts underlying the first and second ridges are imaged as fault-plane reflections that exhibit unusually high amplitudes and polarity reversals at depth but lose amplitude upward and are not imaged in the upper $1.0 \mathrm{~s}$ of the section [MacKay et al., 1992]. Fluid vents and high heat flow values near the outcrop of the frontal thrust (on adjacent lines) [Kulm and Scheidegger, 1979; Langseth and Hobart, 1984; Lewis and Cochrane, 1990] support the
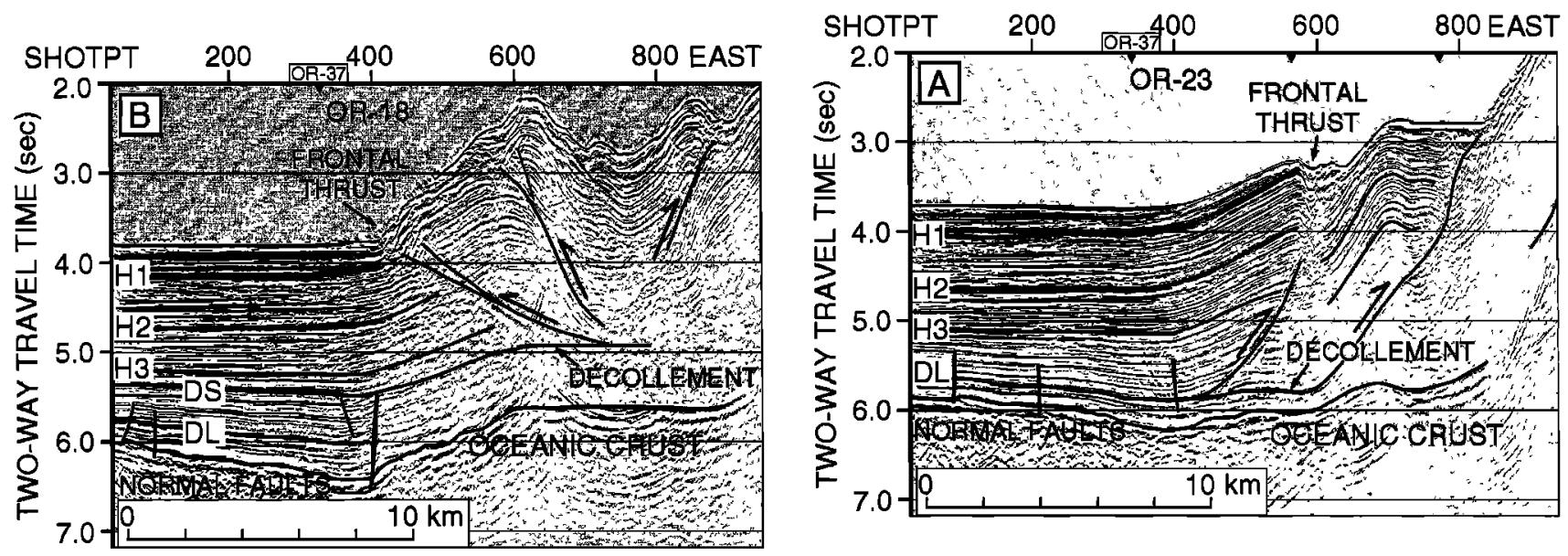

Figure 4. MCS lines (a) OR-05 and (b) OR-18 (location shown in Figure 2), showing near-toe style of deformation typical for Domains III and IV, respectively, displayed without automatic gain control (AGC), so that relative amplitudes are preserved. Vertical scale is two-way travel time in seconds. Vertical exaggeration is approximately $4: 1$ at the seafloor. Seismic horizons shown are shallow horizon, H1; sequence boundary within Unit I, H2; Unit I-Unit II sequence boundary, $\mathrm{H} 3$; incipient décollement in (seaward vergent) Domains I and II, DS, incipient décollement in (landward vergent) Domains III and IV, DL; oceanic crust .

the southern half of the domain (Figure 3 ) but does not reach as far north as line OR-18. The décollement is difficult to image in this region because of the numerous small canyons that cut the seafloor; it appears to lie at the same level as that seen in Domain I.

Domain III (Figure 3) marks the southernmost extent of landward vergence at the toe of the Oregon prism. This region shows a south to north transition in structural style; lower slopes and wider thrust spacing result in a northward outbuilding of the deformation front similar to that observed by Lawton et al. [1994] in the western U.S. Cordilleran. Line OR23 (Figure 5) is typical of Domain III where a distinctive set of three landward vergent anticlinal ridges is easily seen in the Sea Beam bathymetry (Figure 3). The offscraped sediments

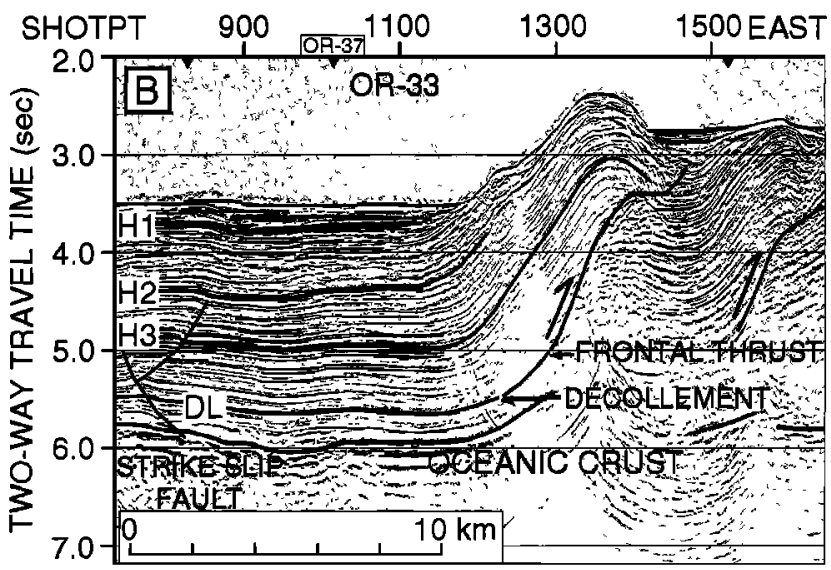

Figure 5. MCS lines (a) OR-23 and (b) OR-33 (location shown in Figure 2), showing near-toe style of deformation typical for Domains III and IV, respectively, displayed without automatic gain control (AGC), so that relative amplitudes are preserved. Vertical scale is two-way travel time in seconds. Vertical exaggeration is approximately $4: 1$ at the seafloor. Seismic horizons shown are shallow horizon, $\mathrm{H} 1$; sequence boundary within Unit I, H2; Unit I-Unit II sequence boundary, $\mathrm{H} 3$; incipient décollement in (seaward vergent) Domains I and II, DS, incipient décollement in (landward vergent) Domains III and IV, DL; oceanic crust . 

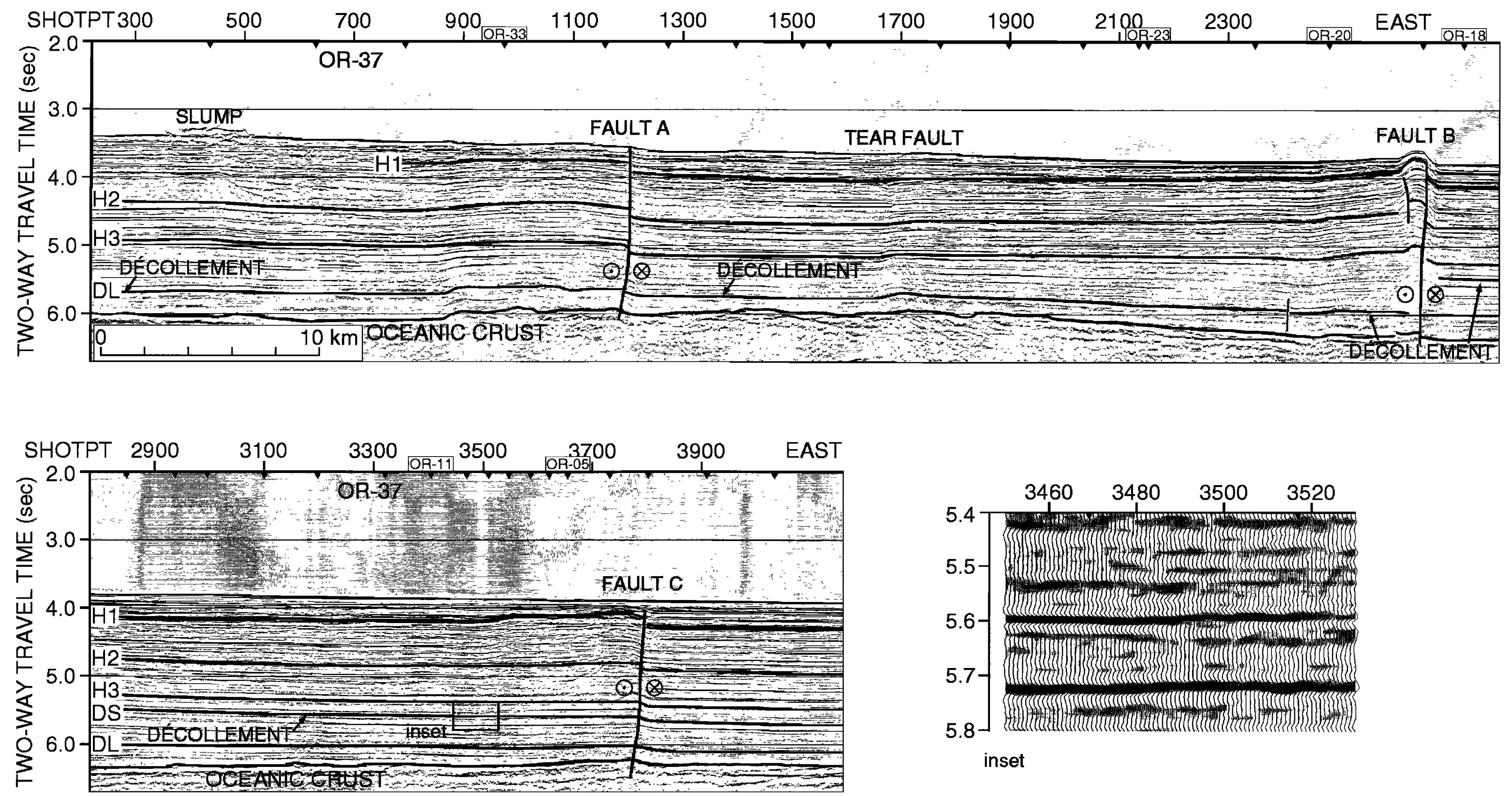
Plate1. MCS line OR-37 (location shown in Figure 2), displayed without automatic gain control (AGC), so that relative amplitudes are preserved. (location shown in Figure 2), showing near-toe style of deformation typical for Domains III and IV, respectively, displayed without automatic gain control (AGC), so that relative amplitudes are preserved. Vertical scale is two-way travel time in seconds. Vertical exaggeration is approximately $4: 1$ at the seafloor. Seismic horizons shown are shallow horizon, H1; sequence boundary within Unit I, H2; Unit I-Unit II sequence boundary, H3; incipient decollement in (seaward vergent) Domains I and II, DS,

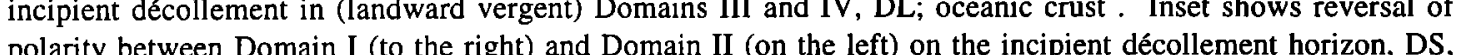
at $5.6 \mathrm{~s}$, shot point 3490. The incipient décollement in Domain It has heen moleled by Cochrane et al.

(1994a) as a reversed-polarity reflection due to high-pore pressure beneath the décollement. 
interpretation of these thrusts as fluid conduits [Moore et al., 1991]. Landward of the three ridges, seaward verging thrust sheets form a series of low ridges that generally display less than $500 \mathrm{~m}$ of relief (Figure 3) [MacKay et al., 1992].

Domain IV is also landward vergent with a deep décollement but has a distinctly different structural style than Domain III (Figure 5b). Widely spaced open folds dominate Domain IV; the resulting anticlinal ridges have very low relief (Figure 3). This style is typical of that found north of the study area across the Oregon and Washington margins [Silver, 1972; Carson, 1977; Barnard; 1978].

\section{Strike-Slip Faults}

Three major strike-slip faults cut Cascadia Basin sediments in the study area (Figure 3). The northernmost of the three, fault A or the Wecoma fault, has been extensively studied [e.g. Appelgate et al., 1992; Goldfinger et al., 1992; MacKay et al., 1992; Tobin et al., 1993] and provides an analog for the two similar faults to the south. All three faults are steeply northeast dipping with a compressional component that results in uplift of trench sediments north of the fault (Plate 1). Estimates of slip rate on the Wecoma fault range from 5-12 $\mathrm{mm} / \mathrm{yr}$ to $7-10 \mathrm{~mm} / \mathrm{yr}$ Appelgate et al. [1992] and Goldfinger et al. [1992], respectively. Goldfinger et al. [1994] estimate $5.5 \mathrm{~km}$ offset on the Wecoma fault; Appelgate et al. [1992] found up to $2.5 \mathrm{~km}$ offset in well-defined surficial features. All three faults cut the entire sedimentary section in the basin and probably involve basement.

\section{Stratigraphic Level of the Décollement}

"Stratigraphic level of the décollement" is used to refer to the basinward extension of the seismic reflector that correlates with the incipient décollement; the décollement is, by definition, a detachment surface. The décollement typically follows stratigraphic horizons that are either inherently weak due to lithology or have low effective stress due to high pore fluid pressure [Westbrook and Smith, 1983]. In a thick sedimentary sequence such as that of the Cascadia Basin, there may be several potential décollement horizons with similar characteristics. Just as the décollement may step either up or down beneath the prism as conditions on the décollement change, the initial level of the décollement may respond to subtle changes in strength that favor one horizon over another. On the Oregon margin the décollement occupies two different horizons, both within the silty distal turbidites of Unit II. Changes in the level of the décollement correspond to structural variations in the adjacent prism; seaward vergent Domains I and II have a shallower décollement than landward vergent Domains III and IV (Figure 6).

\section{The Origin of Landward Vergence}

Although preferred landward vergence dominates the Oregon-Washington margin, it is uncommon elsewhere; seaward vergence typifies accretionary deformation in most areas. Seaward vergence is easily produced in both theoretical and experimental results by introducing a basal shear stress [Hafner, 1951; Davis et al., 1983; Malavieille, 1984; Muguleta, 1988]. For Coulomb failure criteria the orientation
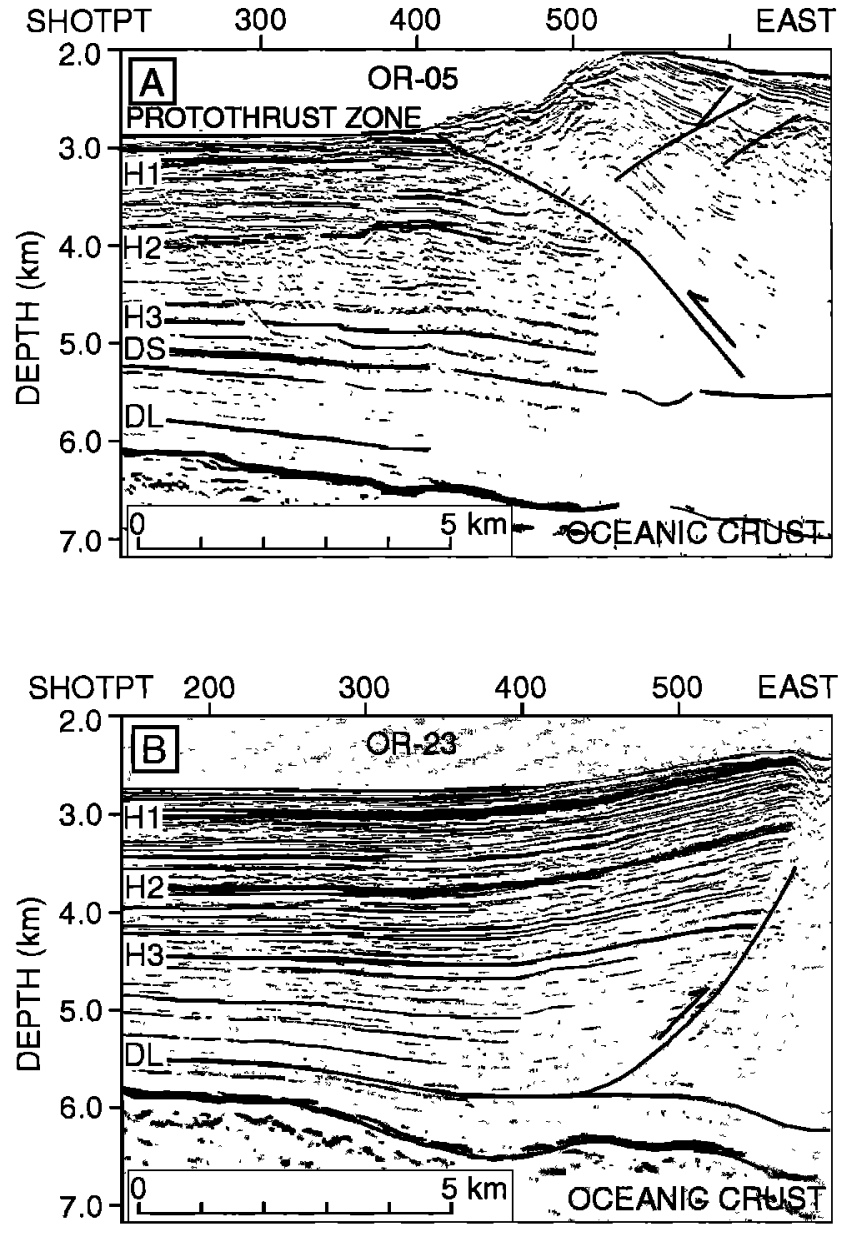

Figure 6. Depth sections for MCS lines MCS lines (a) OR05 and (b) OR-23 (location shown in Figure 2), showing typical seaward vergent (Domain I) and landward vergent (Domain III) style of deformation, respectively, displayed without automatic gain control (AGC), so that relative amplitudes are preserved. Vertical exaggeration is approximately 1.5. Seismic horizons shown are shallow horizon, $\mathrm{H} 1$; sequence boundary within Unit I, H2; Unit I-Unit II sequence boundary, H3; incipient décollement in (seaward vergent) Domains I and II, DS, incipient décollement in (landward vergent) Domains III and IV, DL; oceanic crust .

of potential thrusts is controlled by $\psi_{b}$, the angle between the maximum compressive stress $\left(\sigma_{1}\right)$ and the décollement (Figure 7). Basal shear stress causes $\psi_{b}$ to be much greater than 0 ; therefore the forward vergent thrust planes dip more shallowly than the backward vergent thrusts. In this case, the forward vergent thrusts will be favored because their shallower dip allows them to accommodate a greater amount of horizontal shortening than the steeper dipping back thrusts for a given increase in gravitational potential energy. In cases where basal shear stress is negligible, $\psi_{b}$ approaches 0 and conjugate failure is expected (Figure 8) [Hafner, 1951]. Conjugate or dual-vergence structures are seen in the transitional Domain II along the Oregon margin, as well as the Aleutian margin [Davis and von Huene, 1987], the North Panama fold and 

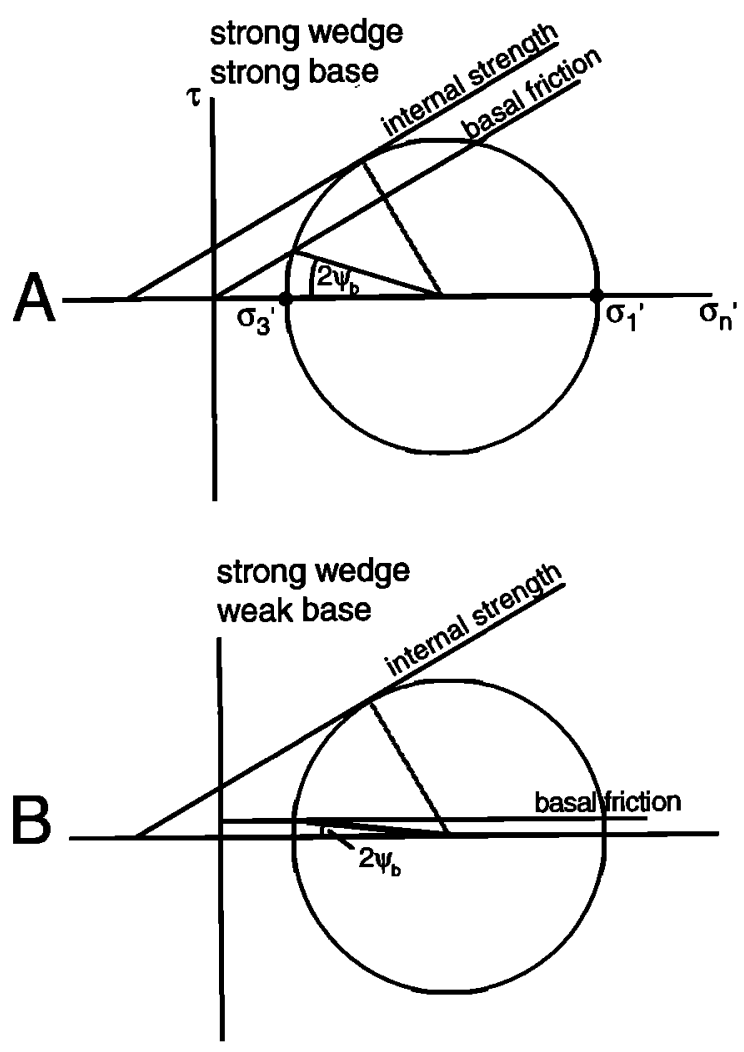

for weak base:

strong wedge $\psi_{\mathrm{b}}<$ weak wedge $\psi_{\mathrm{b}}$

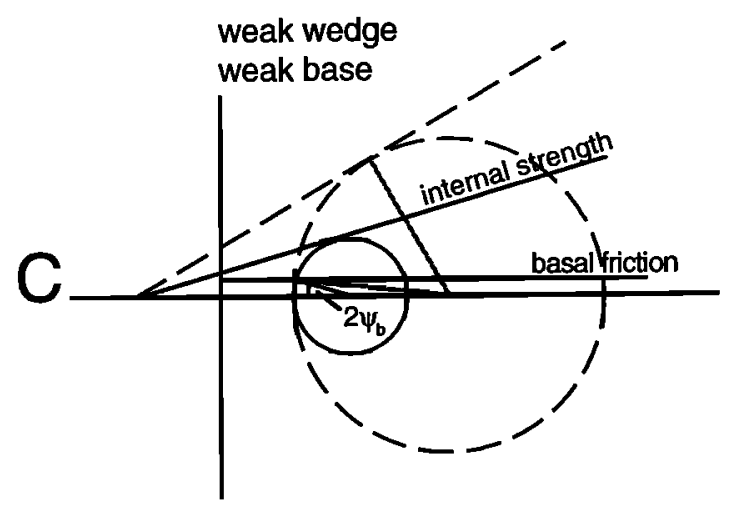

Figure 7. Mohr-Coulomb diagram of effective stress at the base of the wedge, illustrating the relationship between stress orientation angle $y$ and the relative strength of the wedge and basal décollement [after Davis and Engelder, 1985].

thrust belt [Tagudin, 1988], and numerous other locations [Davis and Engelder, 1985].

Seely [1977] proposed that landward vergence along the Washington margin was primarily the result of low basal shear stress due to rapid deposition of trench sediments and attendant overpressuring. Byrne at al. [1993] note that basal friction is the primary control on vergence and that low basal shear stress is essential to the development of landward vergence. Despite these assertions, analytical and experimental models that successfully model other structures in the accre- tionary prism fail to produce purely landward vergence. Where weak detachments and low basal shear stress have been specifically modeled, conjugate thrusts and mixed-vergence structures result [Hafner, 1951; Seely, 1977; Davis and Engelder, 1985; Byrne et al., 1988; Lallemand et al., 1992]. Although low basal shear stress is necessary, it is not, in itself, theoretically or experimentally sufficient to produce landward vergence.

The second essential requirement for preferred landward vergence is an arcward dipping décollement. As Hafner [1951] and others have described, low basal shear stress $\left(\psi_{b} \approx 0\right)$ with a horizontal décollement will produce a conjugate pair of forward and backward vergent thrusts of equal dip (Figure 9a). If however, the décollement dips arcward and $\psi_{b}$ approximates 0 , the backward vergent thrust will dip more shallowly than the forward vergent thrust and will be favored (Figure 9c).
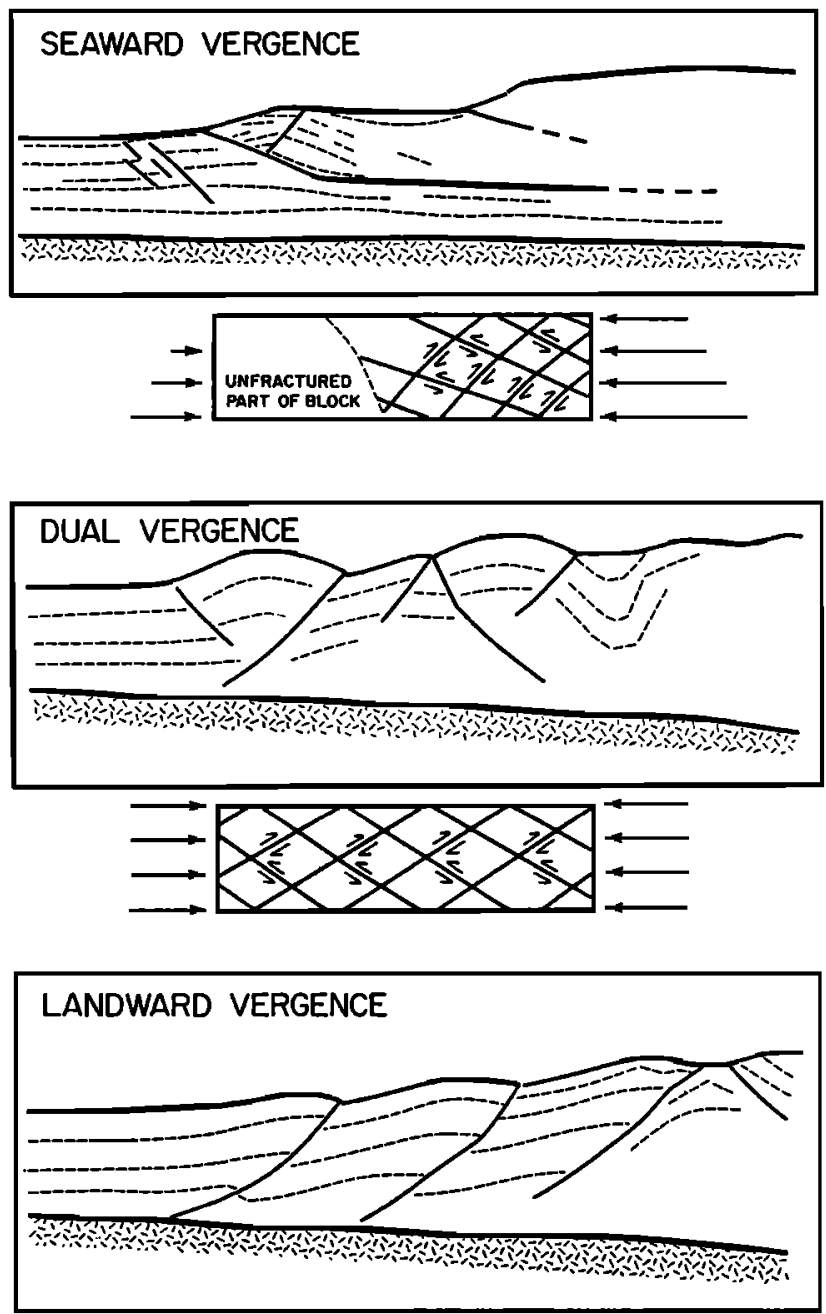

Figure 8. Cartoon showing the style of deformation corresponding to the stress orientation diagrams of Hafner [1951] and similar models. (top) Typical seaward vergence (Domain I) produced by basal shear stress. (middle) Mixed vergence (parts of Domain II) resulting from basal shear stress approximately equal 0 . (bottom) Landward vergence (Domain III), not explained by this conceptual model. 

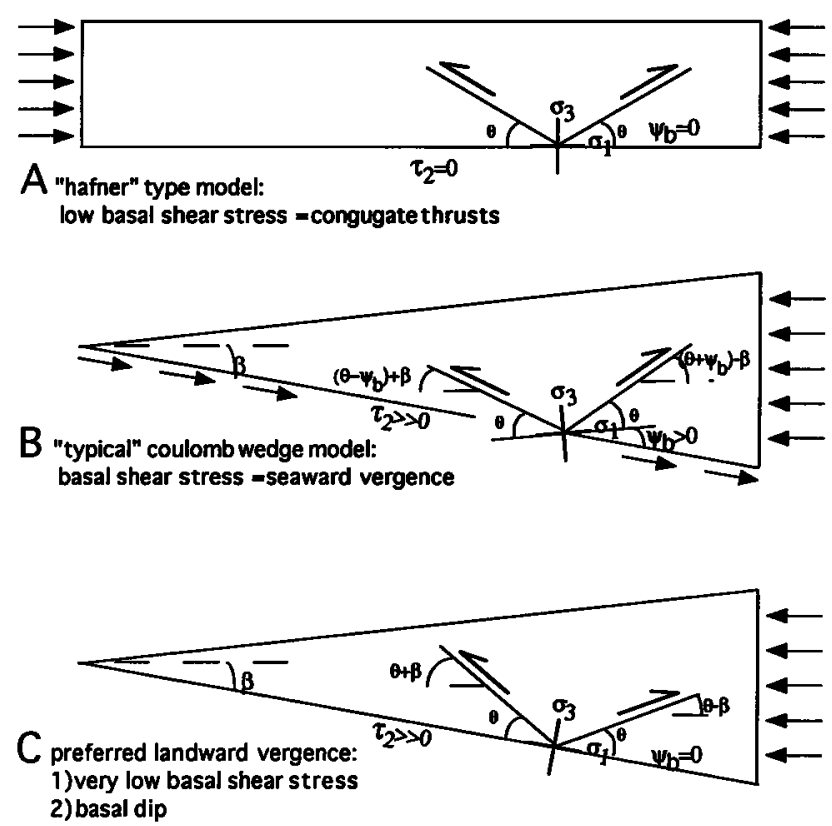

Figure 9. (a-b) The boundary conditions typically used in both experimental and analytical models; (c) the necessary conditions for preferred landward vergence.

A third factor that will influence $\psi_{b}$ and the relative dip of the forward and backward verging thrust planes is the ratio of décollement strength to wedge strength. Where both wedge and base are strong, $\psi_{b}$ is much greater than 0 and seaward vergence is favored (Figure 7). Where the wedge is strong and the base is weak (either intrinsically or due to overpressure), $\psi_{b}$ approximates 0 and either mixed vergence or, if sufficient arcward dip is present, landward vergence, will predominate. For the same low basal shear stress, $\psi_{b}$ will be lower for a strong wedge than for a weak wedge (Figure 7). The theoretical relationship between the ratio of décollement strength to wedge strength and the relative dip of the forward and backward verging thrusts is confirmed by the experimental models of Mulugeta [1988].

Comparison of forward and backward verging (conjugate) protothrusts from OR-20 in the landward vergent region and OR-11 in the seaward vergent region supports the theoretical importance of relative dip and possible differences in basal shear stress (Figure 10). Where seaward vergence is prevalent in the prism, seaward vergent protothrusts have similar dip $\left(38^{\circ}-48^{\circ}\right)$ to their landward vergent counterparts $\left(38^{\circ}-48^{\circ}\right)$. In contrast, where landward vergence dominates the landward vergent protothrusts have a shallower dip $\left(30^{\circ}-33^{\circ}\right)$ than the seaward-vergent protothrusts $\left(36^{\circ}-39^{\circ}\right)$. Although protothrusts are rare in the landward vergent regions of the prism, two other landward vergent lines (not shown) have conjugate protothrusts; on both of these lines the landward vergent protothrust has a shallower dip than the seaward vergent protothrust.

\section{Structural Variation on the Oregon Margin}

The study area spans a regional change in vergence, from seaward vergence to the south to landward vergence in the north. The change to landward vergence is accompanied by a broadening of the continental slope and an increase in thrust spacing [Kulm et al., 1984; MacKay et al., 1992]; these features are consistent with Seely's [1977] interpretation of overpressure and low basal shear stress resulting from rapid Pleistocene sedimentation in the Astoria turbidite system. Within the study area, however, total sediment thickness is approximately constant, and there are no obvious changes in sediment character along strike that might account for the structural variation. Abrupt changes in structural style, the level of the décollement, and the extent of the protothrust zone at the toe of the prism are superimposed on the gradational changes in slope and thrust spacing. These abrupt transitions in structural style coincide with strike-slip faults seen in the basin or with uplift associated with these faults.

Changes in structural style reflect changes in the underlying boundary conditions governing structural development: internal strength of the wedge, basal dip, and basal friction. The internal strength of the wedge may vary on a regional scale due to changes in sediment type, but it is unlikely to account for
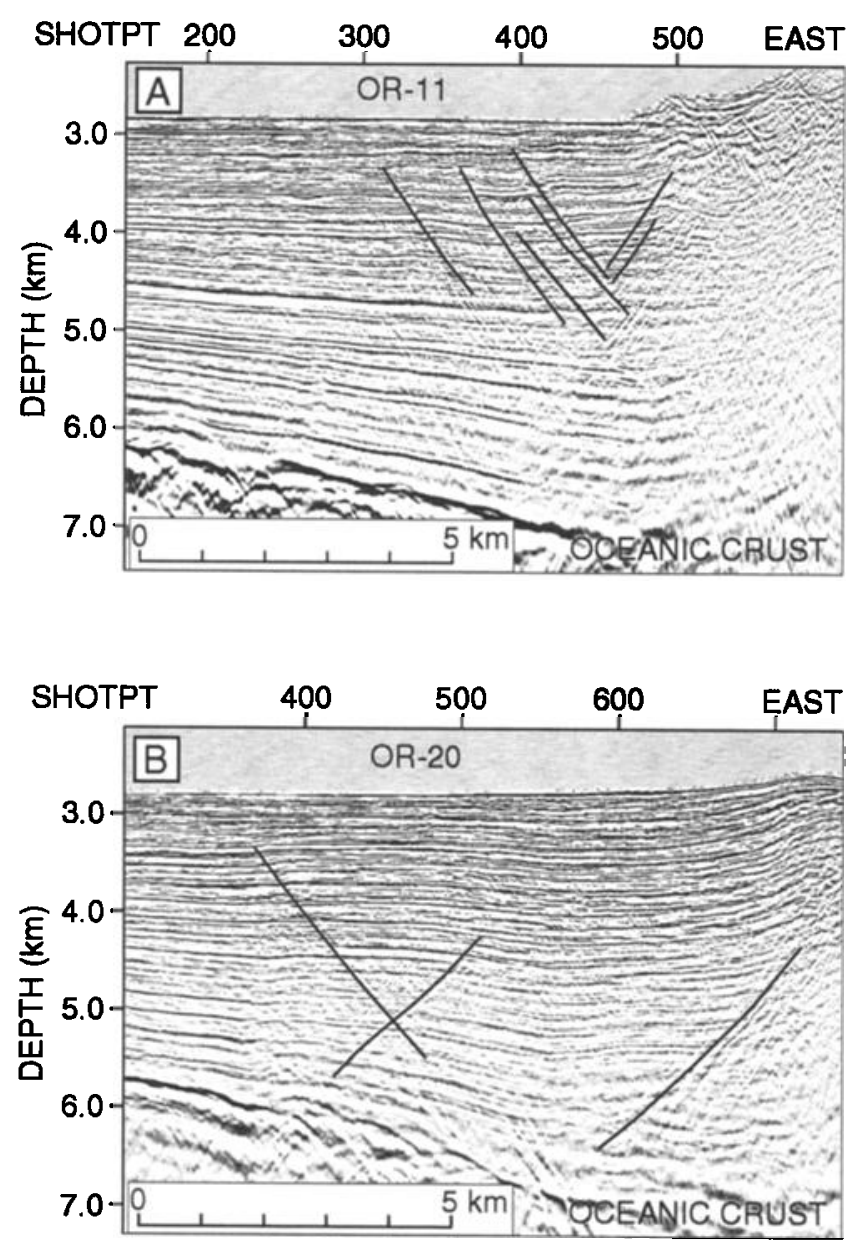

Figure 10. Depth sections for MCS lines (a) OR-11 and (b) OR-20 (location shown in Figure 2), showing conjugate protothrusts in the seaward vergent and landward vergent regions, respectively, displayed without automatic gain control (AGC), so that relative amplitudes are preserved. Vertical exaggeration is approximately 1.5 . 
abrupt changes such as those observed at the domain boundaries. Basal dip in the near-toe region remains constant across the study area. Although there is basement relief across the strike-slip faults, the dip of the incoming plate remains constant at about $4^{\circ}-5^{\circ}$ throughout the survey area [Trehu et al., 1992; Cochrane et al., 1994a]. In Domains I and II, where the décollement is higher in the section, the basal dip is slightly less due to the eastward thickening of the underlying sediments.

In contrast to other boundary conditions, basal friction may change quite rapidly due to changes in pore pressure, and therefore effective stress, on the décollement. Where sediments are deposited (or tectonically thickened) more rapidly than pore fluid can escape, overpressure develops. Assuming that sediments have similar permeability along strike, areas of greater sediment thickness above the décollement will have higher pore pressure on the décollement than areas with less overburden. Because more recent sedimentation has masked the underlying change in sediment thickness (Figure $11 \mathrm{~b}$, hachured region), total thickness above the décollement may not reflect the loading conditions that contribute to overpressure. Figure 3 shows the along-strike change in time thickness of a shallow horizon (H1) and the décollement. The shallow horizon is $0.2-0.4 \mathrm{~s}$ below the seafloor but is the shallowest reflector that can be correlated throughout the survey area; above this level, reflectors become less continuous and minor channels more common (Plate1, horizon H1). The gradual increase in thickness from 33 to $47 \mathrm{~km}$ along strike seen in Figure 3 and
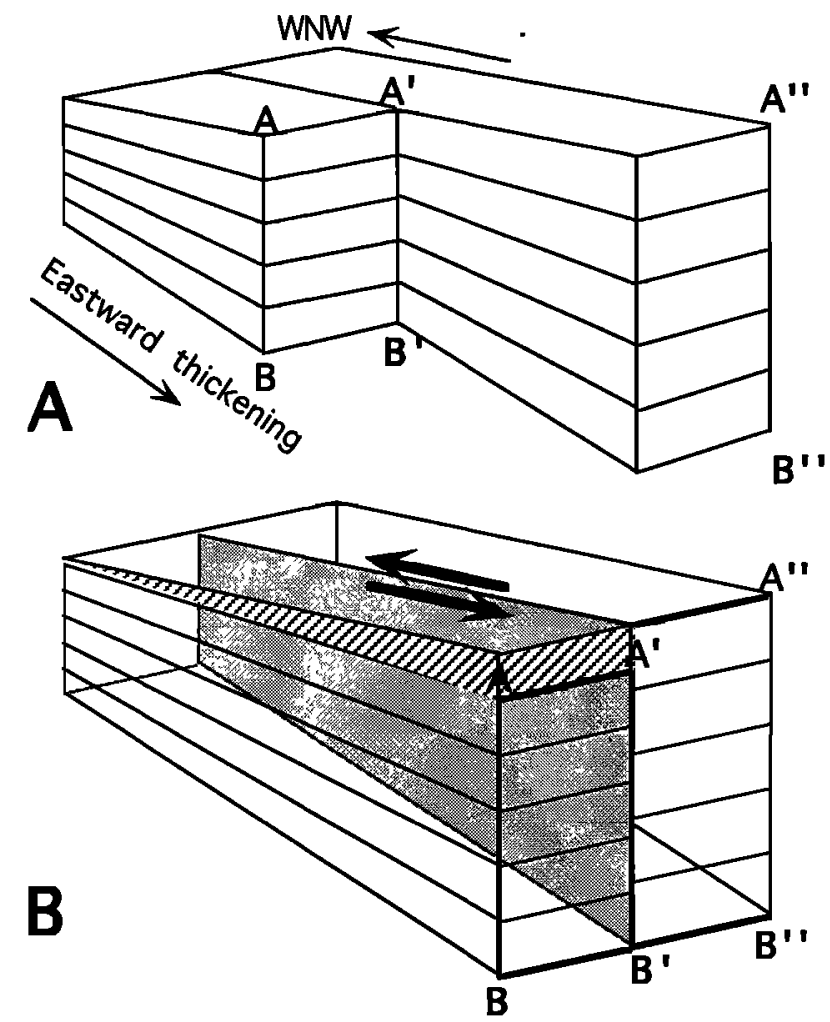

Figure 11. Cartoon showing the juxtaposition of thicker (on the north) and thinner (on the south) sediments due to translation of eastward thickening sediments along a leftlateral strike-slip fault. (a) Prefault geometry, sediments thicken toward the viewer; (b) postfault geometry, thinner sequences on the left (south) side of the fault. generally thicker sediments south of $33 \mathrm{~km}$ result in part from the eastward thickening basin sediments and change in orientation and position of OR-37 (Figure 2); superimposed on this is the change in sediment thickness across the three strikeslip faults. Because the sense of the strike-slip motion is leftlateral [Appelgate et al., 1992; Goldfinger et al., 1992] and the basin sediments thicken eastward, the strike-slip faults juxtapose thicker sequences on the north with thinner (formerly more westward) sequences on the south (Figure 11). The thicker sequences on the north probably result from higher sedimentation rates; if so, there may be a south-tonorth stepwise increase in pore pressure along susceptible horizons [Shi and Wang, 1985].

The fault trace and associated deformation may also perturb the pore pressure conditions in the basin sediments. The northernmost of the three faults, the Wecoma fault, is an active fluid conduit [Tobin et al., 1993]. Its intersection with the margin is complex and results in a localized area of seaward vergence (Figure 3) and higher basal shear stress due to a decrease of pore pressure associated with loss of pore fluid along the fault [Tobin et al., 1993].

In the case of fault $C$, the change in structural style of the prism is not associated with the fault trace but rather with the compressional uplift on the north side of the fault (uplift is shown as hachured region on Figure 3), which affects protothrust development in the seaward vergent region. The protothrust zone is poorly developed immediately north of the uplift and dies out between 63 and $64 \mathrm{~km}$ along strike (Figure 3). Changes in amplitude and polarity along the incipient décollement horizon suggest possible changes in the porefluid pressure at the hinge of the uplift. Seismic modeling of a reversed-polarity interval of the protodecollement in Domain II indicates that the décollement is a low-velocity, high pore pressure, interval [Cochrane et al., 1994a]. The reflector changes polarity (Plate 1, inset) at the boundary between Domain I and Domain II (about $75 \mathrm{~km}$ along strike), coinciding with the hinge of the uplift associated with fault $\mathrm{C}$ (Plate 1). Although many factors may affect reflector polarity, the coincidence of the change in polarity of the protodécollement with the change in structural style of the prism supports the interpretation that the reflector polarity reflects changing pore pressure conditions on the décollement and a northward decrease in basal shear stress.

Once established, landward or seaward vergent deformation may affect pore pressure conditions in the sediments seaward of the prism, influencing the choice and conditions on the décollement. The landward vergent areas develop high velocity, indicative of porosity loss, in the hinge zone above the décollement [MacKay et al., 1995]. If porosity is decreased in the hinge region, the lower porosity sediments may serve to trap fluids at the décollement, thereby enhancing overpressure and promoting the continued development of landward vergence. In contrast, protothrusts in the seaward vergent area appear to act as fluid conduits and may partially drain excess pore pressures from the décollement [Cochrane et al., 1994b].

\section{Conclusions}

Landward vergence requires not only low basal shear stress but also an arcward dipping décollement. A relatively strong wedge is also necessary, to a lesser degree. In order for landward vergence to predominate, these three factors must com- 
bine in such a way that the backward verging thrust planes are favored. Given that the basal dip and sediment type remain almost constant, the most reasonable explanation for changes in structural style across the survey area is changing pore pressure conditions in the Cascadia Basin sediments. Changes in pore fluid pressure affect both stratigraphic position and effective shear stress of the décollement, thereby influencing the structural style and development of landward vergence in the adjacent accretionary prism. The influence of strike-slip faults on the structural style of the prism may reflect subtle differences in pore pressure on the décollement, due to basin deformation and changes in sediment thickness across the faults, that are sufficient to perturb the balance between landward and seaward vergence.

Acknowledgments. This work was supported by National Science Foundation grant OCE-9115924. I thank Greg Moore, Brian Taylor, and Gerard Fryer for comments and discussions in the early stages of this project and Steve Lewis, Eli Silver, and Roland von Huene for helpful reviews. This is School of Ocean and Earth Science and Technology contribution 3905 .

\section{References}

Appelgate, T.B., C. Goldfinger, M.E. MacKay, L.D. Kulm, C.G. Fox, R.W. Embley, and P.J. Meis, A left-lateral strike-slip fault seaward of the central Oregon convergent margin, Tectonics, 11, 465-477, 1992.

Barnard, W.D., The Washington continent slope: Quaternary tectonics and sedimentation, Mar. Geol., 27, 79-114, 1978.

Byme, D.E., D.M. Davis, and L.R. Sykes, Loci and maximum size of thrust earthquakes and the mechanics of the shallow region of subduction zones, Tectonics, 7, 833-857, 1988.

Byrne, D.E., W. Wang, and D.M. Davis, Mechanical role of backstops in the growth of forearcs, Tectonics, 12, 123-144, 1993.

Carson, B., Tectonically induced deformation of deep-sea sediments off Washington and northern Oregon: Mechanical consolidation, Mar. Geol., 24, 289-307, 1977.

Carson, B., E. Suess, and J.C. Strasser, Fluid flow and mass flux determinations at vent sites on the Cascadia Margin Accretionary Prism, J. Geophys. Res., 95, 8891-8897, 1990.

Cochrane, G.R., J.C. Moore, M.E. MacKay, and G.F. Moore, Velocity-porosity model of the Oregon accretionary prism from seismic reflection and refraction data, $J$. Geophys. Res., 99, 7033-7043, 1994a.

Cochrane, G.R., M.E. MacKay, G.F. Moore, and J.C. Moore, Consolidation and deformation of sediments at the toe of the central Oregon accretionary prism from multichannel seismic data, Proc. Ocean Drill. Program Initial Rep., 146, 421-426, 1994 b.

Davis, D.M., and T. Engelder, The role of salt in fold-and-thrust belts, Tectonophysics, 119, 67-88, 1985.

Davis, D M., and R. von Huene, Inferences on sediment strength and fault friction from structures at the Aleutian trench, Geology, 15, 517-522, 1987.

Davis, D.M., J. Suppe, and F.A. Dahlen, Mechanics of fold-and-thrust belts and accretionary wedges, J. Geophys. Res., 88, 1153-1172, 1983.

DeMets, C., R.G. Gordon, D.F. Argus, and S. Stein, Current Plate Motions, Geophys. J. Int., 101, 425-478, 1990.

Goldfinger, C., L.D. Kulm, R.S. Yeats, B. Appelgate, M.E. MacKay, and G.F. Moore, Transverse structural trends along the
Oregon convergent margin: Implications for Cascadia earthquake potential and crustal rotations, Geology, 20, 141-144, 1992.

Goldfinger, C., L.D. Kulm, R.S. Yeats, B. Appelgate, M.E. MacKay, and, G.R. Cochrane, Active strike-slip faulting and folding of the Cascadia plate boundary and forearc in central and northern Oregon, in Earthquake Hazards in the Pacific Northwest, edited by A.M. Rogers, W.J. Kockelman, G. Priest, and T.J. Walsh, U.S. Geol. Surv. Prof. Pap., 1560, 1994.

Hafner, W., Stress distributions and faulting, Geol. Soc. Am. Bull., 62, 373-398, 1951.

Hubbert, M.K., and W.W. Rubey, Role of fluid pressure in mechanics of overthrust faulting; 1. Mechanics of fluid filled porous solids and its application to overthrust faulting, Geol. Soc. Am. Bull., 70, 115-166, 1959.

Kulm, L.D., and K.F. Scheidegger, Quaternary sedimentation on the tectonically active Oregon continental slope, Spec. Publ. Soc. Econ. Paleontol. Mineral., 27, 247-263, 1979.

Kulm, L.D., et al., Initial Reports of the Deep Sea Drilling Project, vol. 18, 1077 pp., U.S. Gov. Print. Off., Washington, D.C., 1973.

Kulm, L.D., et al., (Eds.), Western North American Continental Margin and Adjacent Ocean Floor Off Oregon and Washington. Ocean Margin Drilling Program Regional Atlas Series, Atlas 1, Mar. Sci. Int., Woods Hole, 1984.

Kulm, L.D., et al., Oregon subduction zone: Venting, fauna, and carbonates, Science. 231, 561-566, 1986.

Lallemand, S., J. Malavieille, and S. Calassou, Effects of oceanic ridge subduction on accretionary wedges: Experimental modeling and marine observations, Tectonics, 11 , 1301-1313, 1992.

Langseth, M.G., and A. Hobart, A marine geothermal study over deformed sediments of the subduction complex off Oregon and Washington (abstract), Eos Trans. AGU, 65, 1089, 1984.

Lawton, T.F., S.E. Boyer, and J.G. Schmitt, Influence of inherited taper on structural variability and conglomerate distribution, Cordilleran fold and thrust belt, western United States, Geology, 22, 339-342, 1994.
Lewis B.T.R., and G.C. Cochrane, Relationship between the location of chemosynthetic benthic communities and geologic structure on the Cascadia subduction zone, $J$. Geophys. Res., 95, 8787-8793, 1990.

MacKay, M.E., G.F. Moore, G.R. Cochrane, J.C. Moore, and L.D. Kulm, Landward vergence and oblique structural trends in the Oregon margin accretionary prism: Implications and effect on fluid flow, Earth Planet. Sci. Lett., 109, 477-491, 1992.

MacKay, M.E., G.F. Moore,D. Klaeschen, and R. von Huene, The case against porosity change: Seismic velocity decrease at the toe of the Oregon accretionary prism, Geology, 23, 827-830, 1995.

Malavieille, J., Modelisation experimentale des chevauchements imbiques: Application aux chaines de montagnes, Bull. Soc. Geol. Fr., 7, 129-138, 1984.

Moore, J.C., D. Orange, and L.D. Kulm, Interrelationship of fluid venting and structural evolution: Alvii observations from the frontal accretionary prism, Oregon, $J$. Geophys. Res., 95, 8795-8808, 1990.

Moore, J.C., K.M. Brown, F. Horath, G. Cochrane, M. MacKay, and G. Moore, Plumbing accretionary prisms: Effects of permeability variations, Philos. Trans. $R$. Soc. London A, 335, 275-288, 1991.

Moore, J.C., G.F. Moore, G.R. Cochrane, and H. Tobin, Negative-polarity seismic reflections along faults of the Oregon accretionary prism: Indicators of overpressuring, J. Geophys. Res., 100, 12895-12906, 1995.

Mulugeta, G., Modelling the geometry of Coulomb thrust wedges, J. Struct. Geol., 10, 847-859, 1988.

Orange, D.L., and N.A. Breen, The effects of fluid escape on accretionary wedges, 2 , Seepage force, slope failure, headless submarine canyons, and vents, J. Geophys. Res., 97, 9277-9295, 1992.

Platt, J.P., The mechanics of frontal imbrication: A first-order analysis, Geol. Rundsch. 77, 577-589, 1988.

Seely, D.R., The significance of landward vergence and oblique structural trends on trench inner slopes, in Island Arcs, Deep Sea Trenches, and Back-Arc Basins, Maurice Ewing Ser., vol. 1, edited by M. Talwani and W.C. Pitman, pp. 187-198, AGU, Washington, D.C., 1977. 
Shi, Y., and C. Wang, High pore pressure generation in sediments in front of the Barbados Ridge complex, Geophys. Res. Lett., 12, 773-776, 1985.

Silver, E.A., Pleistocene tectonic accretion of the continental slope off Washington, Mar. Geol., 13, 239-249, 1972.

Tagudin, J.E., A correlation between fault vergence, fault spacing, and sediment type in the North Panama Thrust Belt., M.S. thesis, 32 pp., Univ. of Calif., Santa Cruz, 1988.

Tobin, H.J., J.C. Moore, M.E. MacKay, D.L. Orange, and L.D. Kulm, Fluid flow along a strike-slip fault at the toe of the Oregon accretionary prism: Implications for the ge- ometry of frontal accretion, Geol. Soc. Am. Bull., I05, 569-582, 1993.

Tobin, H.J., J.C. Moore, and G.F. Moore, Fluid pressure in the frontal thrust of the Oregon accretionary prism: Experimental constraints, Geology, 22, 979-982, 1994.

Trehu, A., et al., A crustal cross-section across the Cascadia subduction zone in Central Oregon, Eos Trans. AGU, 73, (43), Fall Meet. Suppl., 391, 1992.

Westbrook, G., and M.J. Smith, Long decollements and mud volcanoes: Evidence from the Barbados Ridge Complex for the role of high pore-fluid pressure in the development of an accretionary complex, Geology, 11, 279-283, 1983.
Westbrook, G., B. Carson, R. Musgrave, and Shipboard Scientific Party, Initial Reports of the Ocean Drilling Program, vol. 146, Part 1, 630 pp., Ocean Drill. Program, College Station, Texas, 1993.

M. E. MacKay, Hawai 'i Institute of Geophysics and Planetology, School of Ocean and Earth Science and Technology, University of Hawai'i Honolulu, HI 96822. (e-mail: mackay@soest.hawaii.edu)

(Received January 12, 1995; revised July 25, 1995;

accepted July 28, 1995.) 